УДК 634.1:631.52

DOI 10.30679/2219-5335-2020-6-66-1-14

БИОЛОГИЧЕСКИЙ ПОТЕНЦИАЛ
ПРОДУКТИВНОСТИ
СОРТОВ ЯБЛОНИ
В УСЛОВИЯХ
ЮЖНОГО РЕГИОНА
РОССИИ

Атабиев Кязим Мурадинович ${ }^{1}$ главный агроном

Ульяновская Елена Владимировна ${ }^{2}$ д-р с.-х. наук зав. лабораторией сортоизучения и селекции садовых культур e-mail: ulyanovskaya_e@mail.ru

Засеева Роксана Муратовна ${ }^{1}$

${ }^{1}$ СПК «Де-Густо», с. Эльхотово, Северная Осетия-Алания, Россия

${ }^{2}$ Федеральное государственное бюджетное научное учреждение «Северо-Кавказский федеральный научный иентр садоводства, виноградарства, виноделия», Краснодар, Россия

По комплексу ценных биологических признаков дана оценка перспективным сортам яблони региональной и зарубежной селекции на подвое ММ 106 в условиях Республики Северная Осетия-Алания.

Исследования проводили согласно общепринятым и разработанным сотрудниками центра селекции ФГБНУ СКФНЦСВВ программам и методикам селекции и сортоизучения плодовых культур. Объекты исследований - генотипы яблони разной плоидности и генетического происхождения.

Всего в изучении был 31 сорт и 1 элитная форма яблони. По итогам многолетних данных экологического сортоиспытания выделены сорта яблони с ранним,
UDC 634.1:631.52

DOI 10.30679/2219-5335-2020-6-66-1-14

\section{BIOLOGICAL POTENTIAL OF PRODUCTIVITY \\ OF APPLE VARIETIES \\ IN THE CONDITIONS \\ OF THE SOUTHERN REGION OF RUSSIA}

Atabiev Kyazim Muradinovich ${ }^{1}$
Chief Agronomist

Ulyanovskaya Elena Vladimirovna ${ }^{2}$

Dr. Sci. Agr.

Head of Laboratory of Variety study and Breeding of Garden crops e-mail: ulyanovskaya_e@mail.ru

Zaseyeva Roksana Muratovna ${ }^{1}$

${ }^{1}$ APC «De-Gousto», v. Elkhotovo, Northern Ossetia-Alania, Russia

${ }^{2}$ Federal State Budget

Scientific Institution

"North Caucasian Federal

Scientific Center of Horticulture, Viticulture, Wine-making», Krasnodar, Russia

According to the complex of valuable biological characteristics it is evaluated the promising apple varieties of regional and foreign selection with MM 106 rootstock under the conditions of North Ossetia-Alania. The studies were carried out in accordance with the generally accepted and developed by the employees of the selection center of the FSBSI NCFSCHVW programs and methods of breeding and variety study. Objects of research is genotypes of apple-trees of different ploidy and genetic origin. In total, there were 31 cultivars and 1 elite apple form in the study. According to the results of long-term data of ecological variety testing, the varieties with early, middle, late and very late dates 
средним, поздним и очень поздним сроком начала вегетации. Выделены сорта

Золотая корона, Золотой поток, Интерпрайс, Любимое Дутовой, Пинк Леди, Прикубанское, Ред Чиф, Чемпион Рено, Флорина, Фуджи и элита 12/2-20-35 с поздним сроком цветения и смешанным типом плодоношения. Установлено, что сорта яблони Пинова, Кармен, Либерти и элита 12/2-20-35 имеют ежегодное обильное цветение (4,8-5,0 баллов) и более высокую среди изученных сортов среднюю урожайность до 38,40-52,63 т/га в условиях Северной Осетии-Алании.

По результатам многолетних исследований выделены перспективные для селекции и производства генотипы яблони Любимое Дутовой и элитная форма 12/2-20-35 с комплексом ценных биологических признаков - ежегодное обильное цветение, поздний срок цветения, смешанный тип плодоношения и высокая продуктивность. Экологическое сортоизучение генотипов яблони различного генетического происхождения в условиях Республики Северная Осетия-Алания позволило выделить и рекомендовать наиболее ценны сорта яблони для использования в селекции и производстве.

Ключевые слова: ЯБЛОНЯ, СОРТ, ЭЛИТНАЯ ФОРМА, ТИП ПЛОДОНОШЕНИЯ, ПРОДУКТИВНОСТЬ of the beginning of the growing season are identified. The apple varieties of Zolotaya Korona, Zolotoy Potok, Interprise, Lyubimoe Dutovoy, Pink Lady, Prikubanskoe, Red Chif, Champion Reno, Florina, Fuji and elite 12/2-20-35 with late flowering and mixed fruiting are selected. It was established that the varieties of Pinova, Carmen, Liberty and elite 12/2-20-35 have annual abundant flowering (4,8-5,0 points) and a higher average yield among the studied varieties - up to $38,40-52$, $63 \mathrm{t} /$ ha under the condition of North Ossetia-Alania. According to the results of many years research, the apple genotypes promising for breeding and production were identified, there are Lyubimoe Dutovoy and the elite form 12/2-20-35 with a complex of valuable biological characteristics annual plentiful flowering, late flowering, mixed fruiting and high productivity. Ecological variety study of apple genotypes of various genetic origin under the conditions of North OssetiaAlania made it possible to select and recommend the most valuable varieties for use in breeding and production.

Key words: APPLE-TREE, VARIETY, ELITE FORM, BEARING TYPE, PRODUCTIVITY

Введение. В последние годы значительное усиление негативного воздействия абио- и биотических стрессоров окружающей среды и их комплекса на многолетнее растение может способствовать серьезному снижению потенциала продуктивности, а также качества получаемой продукции у основных культивируемых сортов плодовых культур, в том числе яблони [1-6]. Считается, что создание идеального сорта - задача, которую не решить, так как основные требования к сортам изменяются быстрее, чем время, необходимое на их создание, но неуклонно стремиться к этому следует [7-8]. 
В Северо-Кавказском регионе России в настоящее время развитие интенсивного адаптивного садоводства предусматривает его биологизацию, которая определяет сорт как основной элемент агросистемы. Развитие экологоадаптивного садоводства основано на максимально возможной реализации биологического потенциала сортов плодовых растений и научно обоснованном их размещении по соответствующим зонам с учетом агроэкологических условий [9-12].

Для успешного решения этой проблемы необходимо создание и выделение сортов с высокими показателями продуктивности и качества плодов, устойчивости к грибным патогенам и абиострессорам среды. Данное направление селекционного совершенствования современного сортимента яблони - создание иммунных и устойчивых к парше сортов с высоким биологическим потенциалом продуктивности и улучшенными коммерческими характеристиками плодов - одно из наиболее приоритетных в настоящее время в мире [2, 4, 8, 13-29].

Известно, что успешное решение основных селекционных задач зависит от правильного подбора исходного материала и определения возможностей использования его ценных признаков и свойств в процессе селекции [3033]. В связи с этим необходимы исследования по выявлению перспективных сортов с комплексом значимых хозяйственных признаков для использования в качестве ценного исходного материала яблони в селекции и обновления современного сортимента.

Цель исследований - выделить на основе многолетних исследований сорта яблони отечественной и зарубежной селекции - источники комплекса хозяйственно ценных признаков для использования в селекции и производстве.

Объекты и методы исследований. Объекты исследований - генотипы яблони (Malus $x$ domestica Borkh.) разной плоидности и генетического происхождения. Всего в изучении было 31 сорт и 1 элитная форма яблони, 
в том числе 17 генотипов отечественной селекции и 15 - зарубежной. Исследовательская работа проведена в 2014-2020 гг. в полевых условиях (СПК «Де-Густо», РСО Алания), в садах яблони общей площадью 18,0 га; подвой MМ 106. Схема посадки 5х2. В работе использованы селекционные программы и методики $[2,4,34]$.

Обсужљение результатов. Производственное и экологическое сортоиспытание как заключительный этап селекционного процесса важен для научно-обоснованного определения региона использования нового сорта или расширения зоны его возделывания, а также получения необходимых рекомендаций по его включению в производство $[2,34]$.

В условиях республики Северной Осетии-Алании для сортов яблони различного эколого-генетического происхождения были определены сроки выхода из периода покоя. Известно, что для выхода растений яблони из состояния вынужденного покоя и активизации ростовых процессов необходима сумма эффективных температур выше $5{ }^{\circ} \mathrm{C}$ - около $30{ }^{\circ} \mathrm{C}[35,36]$. Наступление фенологических фаз отмечали по следующим показателям. Начало распускания почек - на дереве появляются первые лопнувшие генеративные или вегетативные почки. Начало цветения - на деревьях раскрылось около 5-10 \% цветков. Конец цветения - осыпались лепестки с большинства цветков (осталось 5-10 \% цветков).

Выполнение фенологических наблюдений по изучению продолжительности периода покоя позволило разделить сорта и элитные формы яблони на три группы по этому важному биологическому признаку. По результатам многолетних исследований (2014-2020 гг.) выделены сорта с различным сроком начала вегетации:

- ранним: Новелла, Джерсимак, Родничок, Фея;

- средним: Василиса, Кармен, Талисман, Союз, Санрайс, Прима, Редфри, Талисман, Лигол, Гала Галакси, Гала, Щедрость, Любава, Либерти, 
Плодоводство и виноградарство Юга России № 66(6), 2020 г.

Красный янтарь, Пинова, Памяти есаулу, Интерпрайс, 12/2-20-35;

- поздним: Золотой поток, Любимое Дутовой, Чемпион Рено, Ред Чиф, Пинк Леди, Прикубанское, Флорина, Фуджи;

- очень поздним сроком начала вегетации: Золотая корона.

За годы исследований длительность периода от начала набухания почек до их распускания у различных сортов яблони составила от 8 до 24 дней. Сроки цветения в среднем составили до 7-10 дней у сортов яблони, цветущих в ранние сроки; до 8-11 дней - у цветущих в средние сроки; 10-14 дней - у поздноцветущих. Неблагоприятные погодные условия (низкая температура воздуха, осадки) в период цветения увеличивали оптимальные сроки прохождения фенофаз развития растений яблони.

Сроки цветения изученных нами сортов и элитных форм яблони варьируют по годам (табл. 1). Изучение сроков цветения генотипов яблони позволило разделить сорта и элитные формы по этому признаку на три группы: раноцветущие, цветущие в средние сроки и поздноцветущие.

Таблица 1 - Сроки цветения сортов и элитных форм яблони, 2016-2020 гг., РСО-Алания

\begin{tabular}{|c|c|c|c|c|c|c|c|c|c|}
\hline \multirow[b]{2}{*}{$\begin{array}{c}\text { Сорт, } \\
\text { элитная форма }\end{array}$} & \multicolumn{3}{|c|}{ Начало цветения } & \multicolumn{3}{|c|}{ Массовое цветение } & \multicolumn{3}{|c|}{ Конец цветения } \\
\hline & $\begin{array}{c}\text { Среднее } \\
\text { 2016-2018 }\end{array}$ & 2019 & 2020 & $\begin{array}{l}\text { Среднее } \\
\text { 2016-2018 }\end{array}$ & 2019 & 2020 & $\begin{array}{c}\text { Среднее } \\
2016- \\
2018 \\
\end{array}$ & 2019 & 2020 \\
\hline \multicolumn{10}{|c|}{ Ранние сроки } \\
\hline Джерсимак & 21.04 & 22.04 & 18.04 & 24.04 & 25.04 & 22.04 & 30.04 & 30.04 & 28.04 \\
\hline Новелла & 23.04 & 22.04 & 19.04 & 1.05 & 24.04 & 25.04 & 6.05 & 30.04 & 28.04 \\
\hline Санрайс & 23.04 & 23.04 & 19.04 & 28.04 & 28.04 & 26.04 & 5.05 & 4.05 & 30.04 \\
\hline \multicolumn{10}{|c|}{ Средние сроки } \\
\hline Союз & 25.04 & 24.04 & 22.04 & 28.04 & 27.04 & 25.04 & 1.05 & 30.04 & 28.04 \\
\hline Щедрость & 24.04 & 23.04 & 21.04 & 28.04 & 27.04 & 23.04 & 4.05 & 2.05 & 30.04 \\
\hline Пинова & 24.05 & 23.04 & 22.04 & 27.05 & 27.04 & 25.04 & 6.05 & 4.05 & 30.04 \\
\hline Кармен & 25.04 & 23.04 & 20.04 & 29.04 & 26.04 & 24.04 & 7.05 & 30.04 & 1.05 \\
\hline Либерти & 24.04 & 24.04 & 20.04 & 28.04 & 28.04 & 25.04 & 6.05 & 5.05 & 1.05 \\
\hline \multicolumn{10}{|c|}{ Поздние сроки } \\
\hline Флорина & 1.05 & 26.04 & 22.04 & 6.05 & 30.04 & 25.04 & 10.05 & 5.05 & 30.04 \\
\hline Лигол & 27.04 & 25.04 & 22.04 & 2.05 & 29.04 & 25.04 & 7.05 & 2.05 & 30.04 \\
\hline Ред Чиф & 1.05 & 26.04 & 23.04 & 4.05 & 29.04 & 25.04 & 10.5 & 4.05 & 1.05 \\
\hline $12 / 2-20-35$ & 29.04 & 29.04 & 22.04 & 4.05 & 3.05 & 25.04 & 8.05 & 4.05 & 2.05 \\
\hline Любимое Дутовой & 1.05 & 29.04 & 23.04 & 6.05 & 5.05 & 25.04 & 10.05 & 9.05 & 1.05 \\
\hline Золотой поток & 1.05 & 29.04 & 23.04 & 7.05 & 5.05 & 25.04 & 12.05 & 9.05 & 2.05 \\
\hline Пинк Леди & 2.05 & 30.04 & 24.04 & 9.05 & 6.05 & 27.04 & 14.05 & 9.05 & 2.05 \\
\hline Золотая корона & 6.05 & 4.05 & 25.04 & 11.05 & 9.05 & 30.04 & 16.05 & 14.05 & 4.05 \\
\hline
\end{tabular}


Средние сроки начала цветения раноцветущих сортов яблони - третья декада апреля. К первой группе сортов с ранним цветением (средние даты начала цветения, по многолетним данным, 21-23 апреля, в 2020 году - 18-19 апреля) нами отнесены: Джерсимак, Санрайс, Новелла, Фея, Родничок, Рассвет (рис. 1).

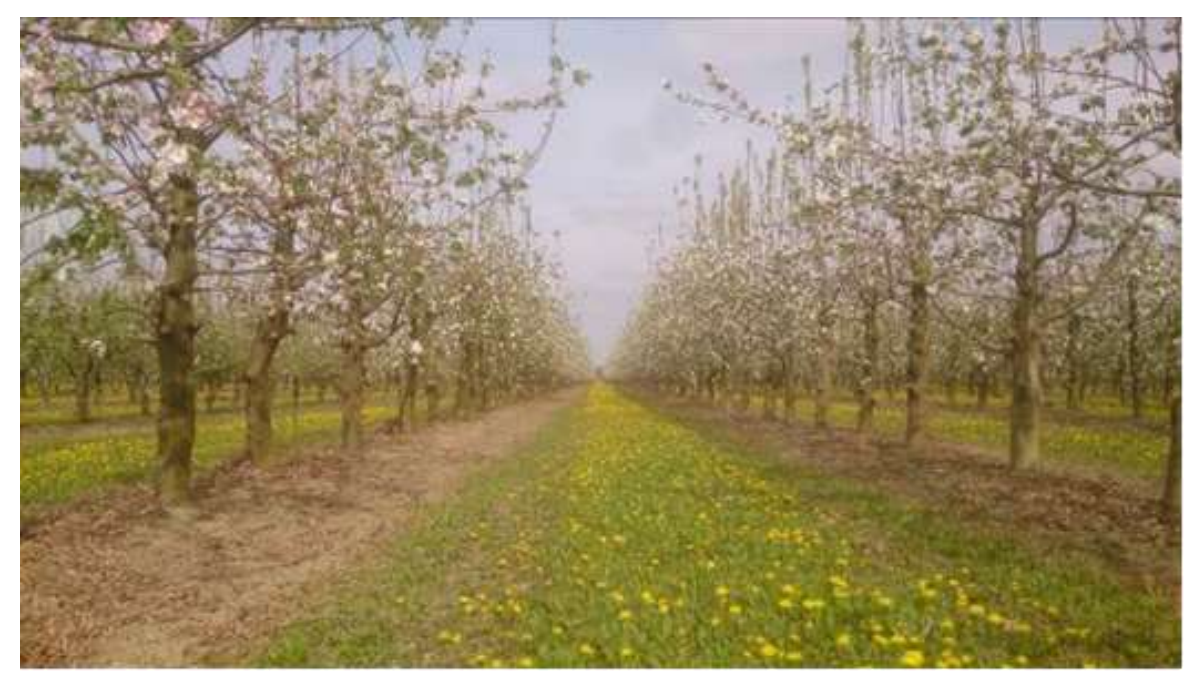

Рис. 1. Цветение сорта яблони Рассвет

Большинство изученных нами сортов яблони включены во вторую группу - цветущих в средние сроки (средние даты начала цветения 24-27 апреля, в 2020 году - 20-22 апреля): Союз, Щедрость, Кармен, Талисман, Редфри, Прима, Красный янтарь, Василиса, Гала, Гала Галакси, Любава, Лигол, Либерти, Пинова, Памяти есаулу, Чемпион Рено.

К третьей группе поздноцветущих отнесены сорта (средние даты начала цветения с 29 апреля по 6 мая, в 2020 году - 22-25 апреля): Ред Чиф, Флорина, Интерпрайс, Прикубанское, Золотая корона, Золотой поток, Любимое Дутовой, Пинк Леди, Фуджи и элитная форма 12/2-20-35.

Среди них наиболее поздний срок цветения по многолетним данным отмечен нами у сортов: Пинк Леди (со 2-3 по 14 мая), Фуджи (с 3 по 14 мая), Золотая корона (с 6 по 16 мая).

Оценку силы цветения учитывали в целом по сорту при проведении фенологических наблюдений за сроками цветения по следующей шкале 
Плодоводство и виноградарство Юга России № 66(6), 2020 г.

(в баллах): 0 - цветения нет; 1 - очень слабое цветение (единичные цветки); 2 - слабое цветение; 3 - среднее цветение; 4 - хорошее цветение; 5 - обильное цветение (табл. 2).

Таблица 2 - Средняя урожайность и сила цветения сортов и элитных форм яблони, 2016-2020 гг., РСО-Алания

\begin{tabular}{|c|c|c|c|c|c|c|c|}
\hline \multirow{2}{*}{$\begin{array}{c}\text { Сорт, } \\
\text { элитная форма }\end{array}$} & \multicolumn{5}{|c|}{ Сила цветения, балл } & \multirow{2}{*}{$\begin{array}{c}\text { Средний балл } \\
\text { цветения } \\
2016-2020 \text { гг. }\end{array}$} & \multirow{2}{*}{$\begin{array}{c}\text { Средняя } \\
\text { урожайность, т/га } \\
2016-2019\end{array}$} \\
\hline & 2016 & 2017 & 2018 & 2019 & 2020 & & \\
\hline \multicolumn{8}{|c|}{ Ранние сроки цветения } \\
\hline Джерсимак & 3 & 4 & 3,5 & 4 & 3 & 3,5 & 15,18 \\
\hline Новелла & 3 & 4 & 3,5 & 3 & 5 & 3,7 & 21,60 \\
\hline Санрайс & 5 & 4 & 5 & 5 & 3 & 4,4 & 26,25 \\
\hline \multicolumn{8}{|c|}{ Средние сроки цветения } \\
\hline Сою3 & 5 & 5 & 3,5 & 4 & 4 & 4,3 & 27,43 \\
\hline Пинова & 5 & 5 & 5 & 5 & 5 & 5 & 52,63 \\
\hline Кармен & 5 & 5 & 5 & 5 & 5 & 5 & 39,53 \\
\hline Либерти & 5 & 5 & 5 & 5 & 5 & 5 & 38,40 \\
\hline \multicolumn{8}{|c|}{ Поздние сроки цветения } \\
\hline Лигол & 2 & 5 & 1 & 3 & 4 & 3 & 28,20 \\
\hline Ред Чиф & 3 & 3 & 5 & 3 & 5 & 3,8 & 25,35 \\
\hline $12 / 2-20-35$ & 5 & 5 & 4 & 5 & 5 & 4,8 & 38,90 \\
\hline Любимое Дутовой & 5 & 5 & 4 & 4 & 5 & 4,6 & 34,50 \\
\hline Золотая корона & 5 & 1 & 5 & 3 & 5 & 3,8 & 33,88 \\
\hline
\end{tabular}

Согласно полученным данным сила цветения изученных нами сортов погодам варьировала от 1,0 до 5,0 баллов. В 2019 году обильное цветение (5,0 баллов) отмечено у сортов: Санрайс, Щедрость, Пинова, Кармен, Либерти, Талисман, Золотой поток, 12/2-20-35. Средний балл цветения у сортов Новелла, Лигол, Ред Чиф, Золотая корона (3,0 балла). В 2020 году обильное цветение (5,0 баллов) отмечено у сортов: Пинова, Кармен, Новелла, Либерти, 12/2-20-35, Ред Чиф, Золотая корона, Любимое Дутовой.

Ежегодное обильное цветение за годы исследования отмечено у сортов Пинова, Кармен, Либерти (5,0 баллов) (рис. 2, 3), достаточно высокий балл цветения (4-5 баллов, среднее значение 4,6-4,8 балла) у сорта Любимое Дутовой и элитной формы 12/2-20-35. Для сортов яблони с ежегодным высоким баллом цветения нами отмечены высокие показатели средней урожайности. Так, сорта зимнего и осеннего сроков созревания Пинова, Кармен, Либерти и элита 12/2-20-35, имеющие ежегодное обильное и хорошее 
цветение в условиях Северной Осетии-Алании (среднее значение силы цветения 4,8-5,0 баллов), обладают также более высокой средней урожайностью - от 38,40 до 52,63 т/га (табл. 2).

Таким образом, можно сделать вывод о том, что достаточно благоприятные агроклиматические условия РСО-Алании позволяют в полной мере реализовать данным сортам и элитам яблони свой биологический потенциал продуктивности. Несомненно, что эти сорта обладают высокой селекционной ценностью и перспективны для использования в производстве.

Поздний срок цветения - ценная биологическая особенность плодовых растений. В кроне одного и того же дерева генеративные почки находятся на различных стадиях дифференциации в связи с тем, что сроки их закладки зависят от биологических особенностей, возраста растения, типа плодового образования, местонахождения в кроне, условий произрастания растения, уровня агротехники.

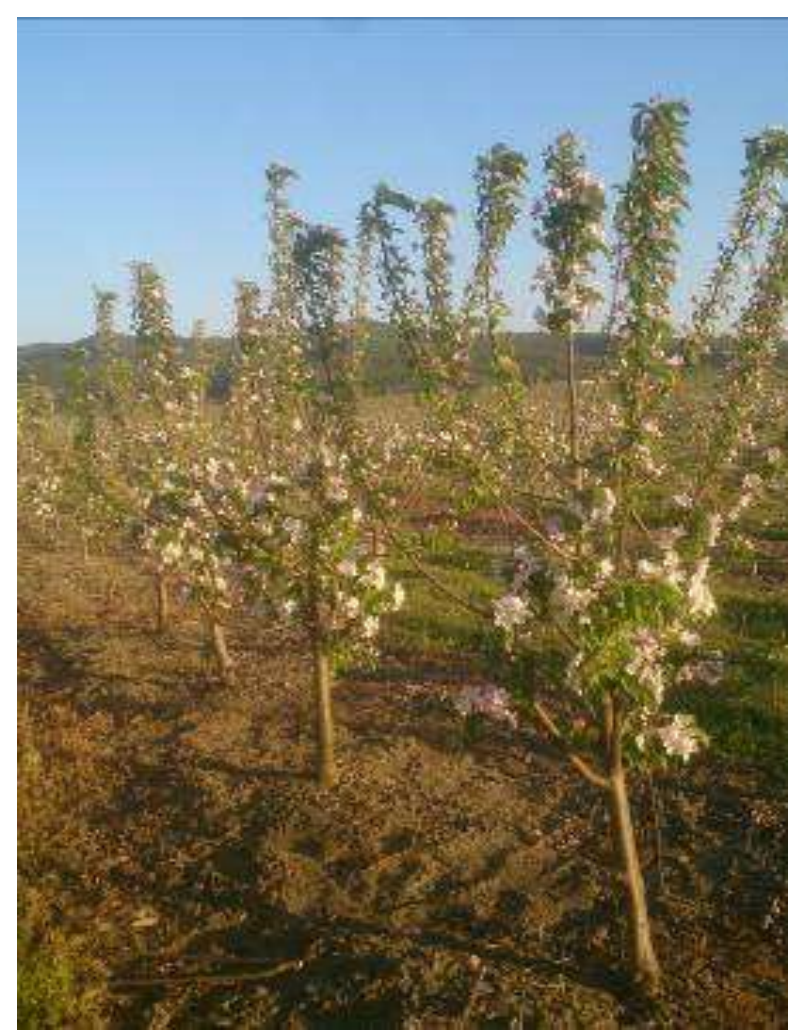

Рис. 2. Цветение сорта яблони Кармен 


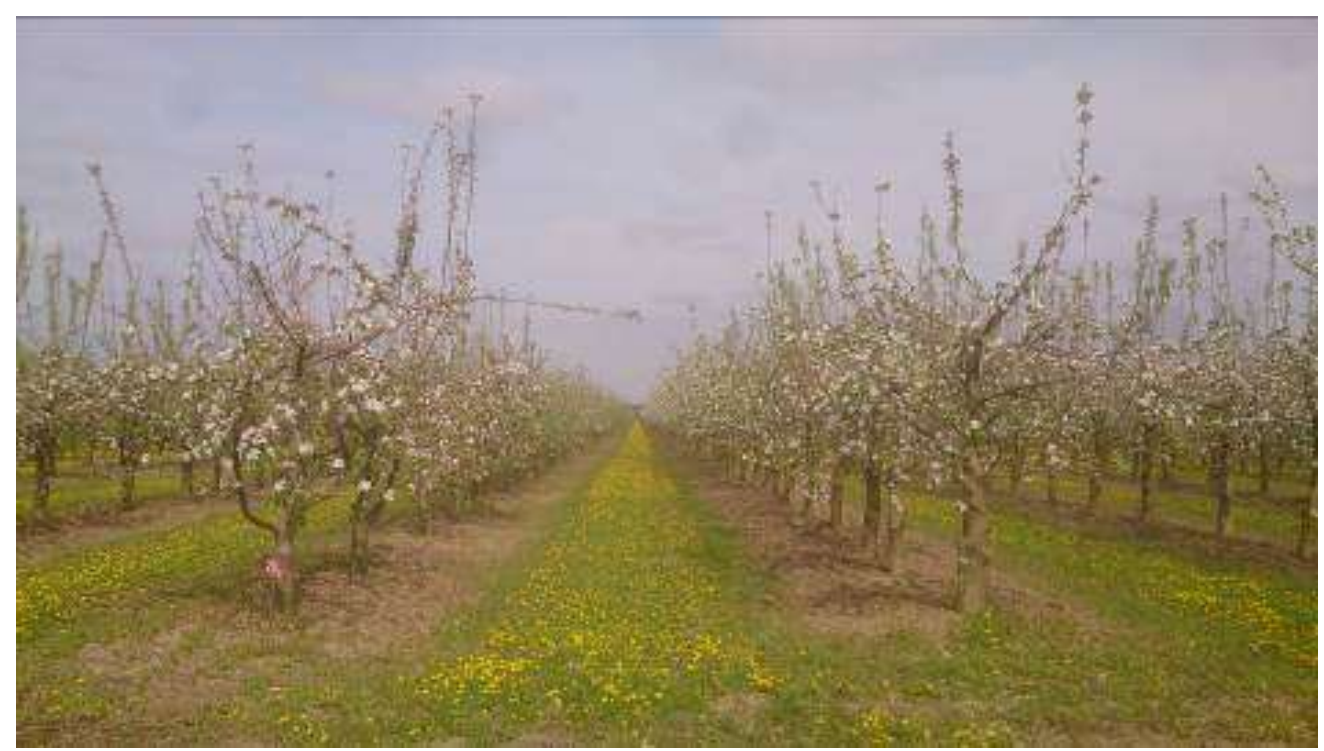

Рис. 3. Цветение сорта яблони Либерти

У разных сортов яблони сроки закладки генеративных почек различны. В более ранние сроки происходит дифференциация генеративных почек яблони на кольчатках, затем - на копьецах и плодовых прутиках, и далее, в последнюю очередь, - на однолетних побегах. В том же порядке происходит цветение растений яблони.

Известно, что сорта яблони с большей экологической устойчивостью обладают смешанным типом плодоношения и поздним сроком цветения. Смешанный тип плодоношения, в отличие от кольчаточного, позволяет в значительной мере снизить в зимне-весенний период потери при транспирации. В период недостаточной активности работы корневой системы позднее цветение, связанное с более поздним развитием листовой поверхности, снижает действие этого негативного процесса. Кроме того, поздний срок цветения позволяет избежать повреждения генеративных органов растения поздневесенними заморозками, которые нередко влияют на продуктивность плодовых культур, в том числе яблони, в южном регионе России.

По результатам многолетних исследований выделены ценные для селекции и производства сорта и элитные формы, сочетающие поздний срок цветения и смешанный тип плодоношения: Золотая корона, Золотой поток, 
Интерпрайс, Любимое Дутовой, Пинк Леди, Прикубанское, Ред Чиф, Чемпион Рено, Флорина, Фуджи 12/2-20-35.

Bbывды. Выявлены закономерности прохождения фенологических фаз развития и биологические особенности формирования продуктивности сортов и элитных форм яблони различного эколого-географического происхождения в условиях РСО-Алании.

Выделены сорта с ранним сроком начала вегетации: Новелла, Джерсимак, Родничок, Фея; средним: Василиса, Кармен, Талисман, Союз, Санрайс, Прима, Редфри, Талисман, Лигол, Гала Галакси, Гала, Щедрость, Любава, Либерти, Красный янтарь, Пинова, Памяти есаулу, Интерпрайс, 12/220-35; поздним: Золотой поток, Любимое Дутовой, Чемпион Рено, Ред Чиф, Пинк Леди, Прикубанское, Флорина, Фуджи; очень поздним сроком начала вегетации: Золотая корона.

Установлена средняя продолжительность периода от цветения до созревания плодов - у раннелетних сортов яблони - 74-87 дней, летних и позднелетних - 101-120 дней, осенних - 126-135 дней и зимних 138-164 дня. Поздний срок цветения и смешанный тип плодоношения имеют сорта: Золотая корона, Золотой поток, Интерпрайс, Любимое Дутовой, Пинк Леди, Прикубанское, Ред Чиф, Чемпион Рено, Флорина, Фуджи и элита 12/2-20-35.

Установлено, что в условиях Северной Осетии-Алании сорта Пинова, Кармен, Либерти и элита 12/2-20-35, имеющие ежегодное обильное и хорошее цветение (4,8-5,0 баллов), обладают более высокой среди изученных сортов средней урожайностью - 38,40-52,63 т/га.

По результатам многолетних исследований выделены перспективные для селекции и производства генотипы яблони Любимое Дутовой и элитная форма 12/2-20-35 с комплексом ценных биологических признаков - ежегодное обильное цветение, поздний срок цветения, смешанный тип плодоношения и высокая продуктивность. 


\section{Литература}

1. Адаптивный потенциал садовых культур юга России в условиях стрессовых температур зимнего периода: методические рекомендации / Е.А. Егоров, И.А. Ильина, Т.Г. Причко [и др.]. Краснодар, 2006. 157 с.

2. Современные методологические аспекты организации селекционного процесса в садоводстве и виноградарстве. Краснодар: СКЗНИИСиВ, 2012. 569 с.

3. Якуба Г.В. Экологизированная защита яблони от парши в условиях климатических изменений. Краснодар, 2013. 213 с.

4. Программа Северо-Кавказского центра по селекции плодовых, ягодных, цветочно-декоративных культур и винограда на период до 2030 года. Краснодар, 2013. 202 с.

5. Комплексная оценка исходного материала яблони для селекции сортов нового поколения / А.Х. Пшеноков, Шидакова А.С., Заремук Р.Ш., Супрун И.И. // Политематический сетевой электронный научный журнал Кубанского государственного аграрного университета. 2013. № 93. С. 889-898.

6. Якуба Г.В. Структура патогенного комплекса возбудителей микозов наземной части растения яблони в условиях изменения климата // Научные труды ГНУ СКЗНИИСиВ. Т. 5. Краснодар: ГНУ СКЗНИИСиВ. 2014. С. 151-157.

7. Кичина В.В. Принципы улучшения садовых растений. М., 2011. 528 с.

8. Седов Е.Н. Селекция и новые сорта яблони. Орел: ВНИИСПК, 2011. 624 с.

9. Заремук Р.Ш., Мамалова Х.Э. Подбор перспективных сортов для оптимизации яблони в условиях Чеченской республики // Политематический сетевой электронный научный журнал Кубанского государственного аграрного университета. - 2014. № 97. С. 718-732.

10. Загиров Н.Г., Бакуев Ж.Х., Атабиев К.М. Продуктивность интенсивных безопорных садов яблони на террасированных склонах // Горное сельское хозяйство. 2015. № 3. C. 86-92.

11. Комплексная оценка агробиологических признаков и экономической эффективности новых устойчивых к парше сортов яблони в условиях Северной Осетии-Алании / Е.В. Ульяновская [и др.]. [Электронный ресурс] // Плодоводство и виноградарство Юга России. 2016. № 39(3). С. 1-11. URL: http://journalkubansad.ru/ pdf/16/03/01.pdf. (дата обращения: 08.10.2020).

12. Ульяновская Е.В., Ермоленко В.Г., Атабиев К.М., Богданович Т.В. Перспективный сортимент яблони для юга России // Научные труды СКФНЦСВВ. Т. 19. Краснодар, СКФНЦСВВ, 2018. С. 19-24.

13. Fischer C., Richter K. Results on fire blight resistance breeding of the Pillnits apple breeding programme / Erwerbsobstbauu, 1999. - V. 41(2). - P. 56-60.

14. Fischer C. Testing scab-resistance stability of new resistant cultivars within the apple breeding program // Fischer C., Schreiber H., Buttner R., Fischer M. / Acta Horticulturae. - 1999. - V. 484. - P. 449-454.

15. Janick J. History of the PRI apple breeding program / Acta Horticulturae. - 2002. V. 595. - P. 55-60.

16. Барсукова О.Н., Хвостова И.В. Генетический потенциал культуры яблони на Северном Кавказе и направления его изучения // Роль сортов и новых технологий в интенсивном садоводстве: материалы к международной научно-методической конференции (Орел, 28-31 июля 2003 г.). Орел, 2003. С. 31-33.

17. Савельев Н.И. Роль сорта в обеспечении устойчивого развития отрасли садоводства на основе инноваций и совершенствования сортимента // Организационно-экономический механизм инновационного процесса и приоритетные проблемы научного обеспечения развития отрасли. Краснодар: СКЗНИИСиВ, 2003. С. 41-44. 
18. Durel C.E. Genetic dissection of partial resistance to rase 6 of Venturia inaequalis in apple // Durel C.E., Parisi L., Laurens F., Van de Weg W.E., Leirbherd R., Jourjon V.F. / Genome. - 2003. - V. 46(2). - P. 224-234.

19. Afunian M.R. Linkage Vfa4 in Malus $x$ domestica and Malus floribunda with Vf resistanse to the apple scab pathogen Venturia inaequalis / Afunian M.R., Goodwin P.H., Hunter D.M. // Plant Pathology. - 2004. - V. 53. - P. 461-467.

20.Седов Е.Н., Седышева Г.А., Серова 3.М., Ульяновская Е.В. Создание новых полиплоидных сортов яблони с генетической устойчивостью к парше // Садоводство и виноградарство, 2009. № 1. С.14-15.

21. Седов Е.Н., Седышева Г.А., Серова 3.М., Ульяновская Е.В. Совершенствование сортимента яблони // Вестник Российской академии сельскохозяйственных наук. 2010. № 4. С. 49-52.

22. Ускоренное создание иммунных к парше сортов яблони с использованием молекулярно-генетических методов исследования / Е.В. Ульяновская [и др.]. Краснодар, $2011.55 \mathrm{c}$.

23. Bus V.G.M. Revision of the nomenclature of the differential host-pathogen interactions of Venturia inaequalis and Malus / Annual Review of Phytopathology. - 2011. V. 49. - P. 391-413.

24. Sedov E., Sedysheva G., Serova Z., Ulyanovskaya E. Creation of triploid grades opens a new era in apple-tree selection / Russian Journal of Horticulture, 2014. - T.1. - № 1. C. 17-24.

25. Козловская 3.А. Селекция яблони в Беларуси. Минск: Беларуская навука, 2015. $457 \mathrm{c}$.

26. Изучение генетического разнообразия современных сортов яблони (Malus domestica) отечественной селекции с использованием микросателлитных локусов / Супрун И.И. [и др.]. // Сельскохозяйственная биология, 2015. Т. 50. № 1. С. 37-45.

27. Савельева Н.Н. Биологические и генетические особенности яблони и селекция иммунных к парше и колонновидных сортов. Мичуринск-наукоград РФ, 2016. 280 с.

28. Макаренко С.А., Калинина И.П. Генетический потенциал в селекции яблони на юге Западной Сибири // Труды по прикладной ботанике, генетике и селекции. 2016. № 177(1). С. 91-109.

29. Барсукова О.Н. Генофонд дикорастущих видов яблони - источник ценных форм для селекции на иммунитет // Идеи Н.И. Вавилова в современном мире: тезисы докладов IV Вавиловской международной научной конференции. Санкт-Петербург, 2017. С. 70.

30. Брюбейкер Дж. Л. Сельскохозяйственная генетика. М.: Колос, 1966. 233 с.

31. Браун А.Д. Яблоня // Селекция плодовых растений. М.: Колос, 1981. С. 13-61.

32. Барсукова О.Н. Перспективы использования коллекции диких видов яблони // Состояние и перспективы селекции и сорторазведения плодовых культур Материалы международной научно-методической конференции, посвященной 160-летию ВНИИСПК (Орел, 12-15 июля 2005 г.). Орел: ВНИИСПК, 2005. С. 290-292.

33. Барсукова О.Н. Изучение и селекционное использования генетического потенциала диких видов яблони // Генетические ресурсы культурных растений в XXI веке: состояние, проблемы, перспективы. Тезисы докладов II Вавиловской международной конференции (26-30 ноября 2007 г.). Санкт-Петербург: ВИР, 2007. С. 409-411.

34. Программа и методика сортоизучения плодовых, ягодных и орехоплодных культур. Орел, 1999. - 606 с.

35. Фулга И.Г., Цуркан И.П., Гоанца И.К. Практическое плодоводство. Кишинев, 1989. $438 \mathrm{c}$.

36. Черепахин В.К., Бабук В.И., Карпенчук Г.К. Плодоводство. М., 1991. 271 с. 


\section{References}

1. Adaptivnyj potencial sadovyh kul'tur yuga Rossii v usloviyah stressovyh temperatur zimnego perioda: metodicheskie rekomendacii / E.A. Egorov, I.A. Il'ina, T.G. Prichko [i dr.]. Krasnodar, 2006. 157 s.

2. Sovremennye metodologicheskie aspekty organizacii selekcionnogo processa v sadovodstve i vinogradarstve. Krasnodar: SKZNIISiV, 2012. $569 \mathrm{~s}$.

3. Yakuba G.V. Ekologizirovannaya zashchita yabloni ot parshi v usloviyah klimaticheskih izmenenij. Krasnodar, 2013. 213 s.

4. Programma Severo-Kavkazskogo centra po selekcii plodovyh, yagodnyh, cvetochno-dekorativnyh kul'tur i vinograda na period do 2030 goda. Krasnodar, 2013. $202 \mathrm{~s}$.

5. Kompleksnaya ocenka iskhodnogo materiala yabloni dlya selekcii sortov novogo pokoleniya / A.H. Pshenokov, Shidakova A.S., Zaremuk R.Sh., Suprun I.I. // Polite-maticheskij setevoj elektronnyj nauchnyj zhurnal Kubanskogo gosudarstvennogo agrarnogo universiteta. 2013. № 93. S. 889-898.

6. Yakuba G.V. Struktura patogennogo kompleksa vozbuditelej mikozov nazemnoj chasti rasteniya yabloni $\mathrm{v}$ usloviyah izmeneniya klimata // Nauchnye trudy GNU SKZNIISiV. T. 5. Krasnodar: GNU SKZNIISiV. 2014. S. 151-157.

7. Kichina V.V. Principy uluchsheniya sadovyh rastenij. M., 2011. $528 \mathrm{s.}$

8. Sedov E.N. Selekciya i novye sorta yabloni. Orel: VNIISPK, 2011. 624 s.

9. Zaremuk R.Sh., Mamalova H.E. Podbor perspektivnyh sortov dlya optimizacii yabloni v usloviyah Chechenskoj respubliki // Politematicheskij setevoj elektronnyj nauchnyj zhurnal Kubanskogo gosudarstvennogo agrarnogo universiteta. - 2014. № 97. S. 718-732.

10. Zagirov N.G., Bakuev Zh.H., Atabiev K.M. Produktivnost' intensivnyh bezopornyh sadov yabloni na terrasirovannyh sklonah // Gornoe sel'skoe hozyajstvo. 2015. № 3. S. 86-92.

11. Kompleksnaya ocenka agrobiologicheskih priznakov i ekonomicheskoj ef-fektivnosti novyh ustojchivyh k parshe sortov yabloni v usloviyah Severnoj Osetii-Alanii / E.V. Ul'yanovskaya [i dr.]. [Elektronnyj resurs] // Plodovodstvo i vinogradarstvo Yuga Rossii. 2016. № $\quad 39(3)$. S. 1-11. URL: $\quad$ http://journalkubansad.ru/pdf/16/03/01.pdf. (data obrashcheniya: 08.10.2020).

12. Ul'yanovskaya E.V., Ermolenko V.G., Atabiev K.M., Bogdanovich T.V. Perspektivnyj sortiment yabloni dlya yuga Rossii // Nauchnye trudy SKFNCSVV. T. 19. Krasnodar, SKFNCSVV, 2018. S. 19-24.

13. Fischer C., Richter K. Results on fire blight resistance breeding of the Pillnits apple breeding programme / Erwerbsobstbauu, 1999. - V. 41(2). - P. 56-60.

14. Fischer C. Testing scab-resistance stability of new resistant cultivars within the apple breeding program // Fischer C., Schreiber H., Buttner R., Fischer M. / Acta Horticul-turae. - 1999. - V. 484. - P. 449-454.

15. Janick J. History of the PRI apple breeding program / Acta Horticulturae. - 2002. V. 595. - P. 55-60.

16. Barsukova O.N., Hvostova I.V. Geneticheskij potencial kul'tury yabloni na Severnom Kavkaze i napravleniya ego izucheniya // Rol' sortov i novyh tekhnologij v intensivnom sadovodstve: materialy k mezhdunarodnoj nauchno-metodicheskoj konferencii (Orel, 28-31 iyulya 2003 g.). Orel, 2003. S. 31-33.

17. Savel'ev N.I. Rol' sorta v obespechenii ustojchivogo razvitiya otrasli sadovodstva na osnove innovacij i sovershenstvovaniya sortimenta // Organizacionno-ekonomicheskij mekhanizm innovacionnogo processa i prioritetnye problemy nauchnogo obespecheniya razvitiya otrasli. Krasnodar: SKZNIISiV, 2003. S. 41-44. 
18. Durel C.E. Genetic dissection of partial resistance to rase 6 of Venturia inaequalis in apple // Durel C.E., Parisi L., Laurens F., Van de Weg W.E., Leirbherd R., Jourjon V.F. / Genome. - 2003. - V. 46(2). - P. 224-234.

19. Afunian M.R. Linkage Vfa4 in Malus $x$ domestica and Malus floribunda with Vf resistanse to the apple scab pathogen Venturia inaequalis / Afunian M.R., Goodwin P.H., Hunter D.M. // Plant Pathology. - 2004. - V. 53. - P. 461-467.

20. Sedov E.N., Sedysheva G.A., Serova Z.M., Ul'yanovskaya E.V. Sozdanie novyh poliploidnyh sortov yabloni s geneticheskoj ustojchivost'yu k parshe // Sadovodstvo i vinogradarstvo, 2009. № 1. S.14-15.

21. Sedov E.N., Sedysheva G.A., Serova Z.M., Ul'yanovskaya E.V. Sovershenstvovanie sortimenta yabloni // Vestnik Rossijskoj akademii sel'skohozyajstvennyh nauk. 2010. № 4. S. 49-52.

22. Uskorennoe sozdanie immunnyh $\mathrm{k}$ parshe sortov yabloni s ispol'zovaniem molekulyarno-geneticheskih metodov issledovaniya / E.V. Ul'yanovskaya [i dr.]. Krasnodar, 2011. $55 \mathrm{~s}$.

23. Bus V.G.M. Revision of the nomenclature of the differential host-pathogen interactions of Venturia inaequalis and Malus / Annual Review of Phytopathology. - 2011. V. 49. - P. 391-413.

24. Sedov E., Sedysheva G., Serova Z., Ulyanovskaya E. Creation of triploid grades opens a new era in apple-tree selection / Russian Journal of Horticulture, 2014. - T.1. - № 1. S. 17-24.

25. Kozlovskaya Z.A. Celekciya yabloni v Belarusi. Minsk: Belaruskaya navuka, 2015. $457 \mathrm{~s}$.

26. Izuchenie geneticheskogo raznoobraziya sovremennyh sortov yabloni (Malus domestica) otechestvennoj selekcii s ispol'zovaniem mikrosatellitnyh lokusov / Suprun I.I. [i dr.]. // Sel'skohozyajstvennaya biologiya, 2015. T. 50. № 1. S. 37-45.

27. Savel'eva N.N. Biologicheskie i geneticheskie osobennosti yabloni i selekciya immunnyh k parshe i kolonnovidnyh sortov. Michurinsk-naukograd RF, 2016. $280 \mathrm{~s}$.

28. Makarenko S.A., Kalinina I.P. Geneticheskij potencial v selekcii yabloni na yuge Zapadnoj Sibiri // Trudy po prikladnoj botanike, genetike i selekcii. 2016. № 177(1). S. 91-109.

29. Barsukova O.N. Genofond dikorastushchih vidov yabloni - istochnik cennyh form dlya selekcii na immunitet // Idei N.I. Vavilova v sovremennom mire: tezisy dokladov IV Vavilovskoj mezhdunarodnoj nauchnoj konferencii. Sankt-Peterburg, 2017. S. 70.

30. Bryubejker Dzh. L. Sel'skohozyajstvennaya genetika. M.: Kolos, 1966. $233 \mathrm{~s}$.

31. Braun A.D. Yablonya // Selekciya plodovyh rastenij. M.: Kolos, 1981. S. 13-61.

32. Barsukova O.N. Perspektivy ispol'zovaniya kollekcii dikih vidov yabloni // Sostoyanie i perspektivy selekcii i sortorazvedeniya plodovyh kul'tur: materialy mezhdunarodnoj nauchno-metodicheskoj konferencii, posvyashchennoj 160-letiyu VNIISPK (Orel, 12-15 iyulya 2005 g.). Orel: VNIISPK, 2005. S. 290-292.

33. Barsukova O.N. Izuchenie i selekcionnoe ispol'zovaniya geneticheskogo po-tenciala dikih vidov yabloni // Geneticheskie resursy kul'turnyh rastenij v XXI veke: sostoyanie, problemy, perspektivy: tezisy dokladov II Vavilovskoj mezhdunarod-noj konferencii (26-30 noyabrya 2007 g.). Sankt-Peterburg: VIR, 2007. S. 409-411.

34. Programma i metodika sortoizucheniya plodovyh, yagodnyh i orekhoplodnyh kul'tur. Orel, 1999. - 606 s.

35. Fulga I.G., Curkan I.P., Goanca I.K. Prakticheskoe plodovodstvo. Kishinev, 1989. $438 \mathrm{~s}$.

36. Cherepahin V.K., Babuk V.I., Karpenchuk G.K. Plodovodstvo. M., 1991. 271 s. 